\title{
R\&D spending and patents: levers of national development
}

Levers of national development

\author{
Fábio de Oliveira Paula and Jorge Ferreira da Silva \\ IAG Business School, Pontifical Catholic University of Rio de Janeiro, \\ Rio de Janeiro, Brazil
}

\begin{abstract}
Purpose - The level of R\&D spending of a country tends to increase the national patent rate and, in consequence, can collaborate with its economic development. However, there are a few empirical studies investigating this phenomenon by comparing countries from all over the globe. The purpose of this paper is to disassemble the sources of R\&D spending and identify the role of national patent applications as a mediator in the relationship between R\&D spending and national development.

Design/methodology/approach - Panel data on patent applications in 35 countries of all continents (except Africa) over 15 years (from 1999 to 2013) regarding four levels of national R\&D intensity (i.e. by enterprises, governments, higher education institutions and private non-profit organisations), gross domestic product (GDP) per capita, gross national income (GNI) and human development index (HDI) were collected from the OCDE. Then, two-stage panel regressions were conducted to test the hypotheses.

Findings - The empirical findings indicated that R\&D spending from firms and higher education institutions (public and private) help to directly improve national patent applications, thus contributing to the national development (measured by GDP per capita, GNI per capita and HDI).

Originality/value - The importance of this study was to show that the investments in R\&D made by universities and firms are more effective in leading to patent applications, which contributes to promoting national development. With these findings, governments can focus their efforts on stimulating these types of investments if they want to foster the growth of national patent rates.
\end{abstract}

Keywords Innovation, R\&D spending, Patent applications, National development

Paper type Research paper

\section{Introduction}

The academy has been studying the relationship between the introduction of innovation by firms and their financial performance extensively. Most scholars agree that this relationship should be positive (Du, Leten, \& Vanhaverbeke, 2014; Yamakawa, Yang, \& Lin, 2011) for several reasons. Considering the four types of innovation proposed by the Oslo Manual (OECD, 2005), product innovation allows the firms to fulfil gaps in demand (Galindo \& Méndez, 2014) by launching new products with better costs or quality (Ateljević \& Trivić, 2016). Process

(C) Fábio de Oliveira Paula and Jorge Ferreira da Silva. Published in Innovation and Management Review. Published by Emerald Publishing Limited. This article is published under the Creative Commons Attribution (CC BY 4.0) licence. Anyone may reproduce, distribute, translate and create derivative works of this article (for both commercial and non-commercial purposes), subject to full attribution to the original publication and authors. The full terms of this licence maybe seen at http:// creativecommons.org/licences/by/4.0/legalcode

This work was supported by FAPERJ (Foundation for Research Support of the State of Rio de Janeiro - Brazil) under Grants E-26/202.864/2018 (239233) and E-26/210.277/2019(248665) and CNPq (National Council for Scientific and Technological Development - Brazil) under Grants 305706/2015-2 and 406559/2018-0.

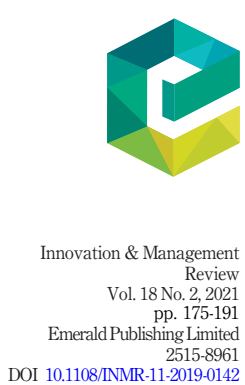

Received 26 November 2019

Revised 15 April 2020 6 July 2020

Accepted 20 August 2020 
INMR 18,2

innovations promote cost reduction and increases in productivity by improving the production process (Moutinho, Au-Yong-Oliveira, Coelho, \& Pires Manso, 2015; Terjesen \& Patel, 2017). Organizational innovation brings greater resilience to the external environment through strategic renewal (Hamel \& Valikangas, 2004). Marketing innovation, in turn, increases the competitiveness of a brand (Gupta, Malhotra, Czinkota, \& Foroudi, 2016). However, there are research lines proposing that this influence is reverse, that is, a positive financial performance increases the innovativeness (Ryu \& Lee, 2018) in which unsuccessful firms invest their resources on basic operations rather than on innovation. Some empirical studies, in turn, did not find any relationship between both constructs (Paula \& Silva, 2018).

When it comes to innovation, patenting is one of the most related issues. Several authors in the field of innovation management have used patents as a proxy for firm innovation performance (Hagedoorn \& Wang, 2012; Schilling, 2015) and country innovativeness (Jemala, 2017). However, more recent studies disagree with the adequacy of this variable as an innovation measurement (Chambers, 2016). In fact, patents are more related to the registration of inventions than to their effective application (Merges, 1988), which would turn the invention into an innovation. Moreover, they are useful as an appropriability mechanism to protect product innovation from counterfeiting (Hall, Helmers, Rogers, \& Sena, 2014; Wang, Lo, \& Liao, 2015) in specific sectors (Pavitt, 1984), such as the pharmaceutical industry (Su \& Lin, 2018). The importance of patents in the innovation system, therefore, should not be neglected. Besides representing a share of the innovation introduced into the market, it is one of the most effective protection mechanisms for innovation in many industries, as demonstrated by several empirical studies (Amara, Landry, \& Traoré, 2008; Hall \& Sena, 2017; Lee, John, Fong, \& Bao, 2018;)

It is generally recognised that it is more difficult to understand an individual behaviour than a collective one. Considering that the above-mentioned reasons consistently support that patents should help improve the firm's performance (either directly, as a product innovation to increase sales, or indirectly, by guaranteeing the appropriability of innovation revenues), one may conclude that, collectively, the firms in a country should have their performances boosted by the total of patents at the national level. Patents could also help promote economic development and well-being for the population. Some facts support this supposition. For example, 24 out of the 30 leaders of the Global Innovation Index - GII (Dutta, Lanvin, \& Wunsch-Vincent, 2019) are among the 30 countries with higher projected nominal GDP per capita in 2019 (Statistics Times, 2019). Despite this apparent correlation, causality is not guaranteed, since a more prosperous country may apply and grant more patents as a result of increased investments stimulated by its wealth (Orihata, 2001). Moreover, a group of successful firms patenting a lot in the same region may not automatically cause regional development. For instance, new automated entrants (with lots of patents related to their process innovations) might be substituting old incumbents and destroying jobs. The conflicting results of previous studies support that more research on patents and regional or national development by using new methods, proxies and databases are needed. Beugelsdijk (2007), in a sample of 54 European regions, found a positive influence of patents on regional growth per capita, represented by GDP per capita. On the other hand, studies such as the one by Shearmur and Bonnet (2011) indicated that patent applications were not related to local development in terms of employment growth in Canada.

The academic literature has extensively explored the relationship between R\&D, patenting and performance at the firm level, whereas studies at a regional or national level are scarce. Specifically concerning R\&D investments, studies on the effectiveness of national 
investments on R\&D conducted by different stakeholders are rare. To tackle this identified literature gap, this study intends to investigate the effect of patenting and R\&D investments on growth of national economies and population well-being by proposing the following research question:

$R Q 1$. How does the sum of investments in R\&D made by diverse stakeholders (i.e. firms, governments, universities and non-profit organisations) and total patents at the national level influence a country's development?

The importance of analysing this research question is reinforced not only by the high spending on R\&D nowadays, but also by the cost and effort the patent application process demands from firms, including high investments for maintenance of an effective patenting system with all mechanisms of legal protection a country needs to make.

To answer the proposed research question, the present study formulated five hypotheses regarding the influence of national investments in $R \& D$ by the four stakeholders cited above, patent application and national development. National development was measured by using gross domestic product (GDP) per capita, gross national income (GNI) per capita and human development index (HDI). Data on 35 countries from the OECD statistics database (OECD, 2018) covering the years of 1999 to 2013 were used for study and estimation was conducted by using panel regression analysis (robust least squares).

We structured this study as follows: firstly, a literature review on studies related to the subject and formulation of hypotheses; secondly, methods describing data and selecting sample, variables, model and statistic analysis. Thirdly, a description of the results and presentation of conclusion.

\section{Literature review}

At the beginning of the 20th century, Schumpeter highlighted the importance of new combinations, or innovations, to create discontinuities in the market necessary for economic development (Schumpeter, 1934). The importance of innovation has increased with the dynamism and uncertainty involved in today's business environments (Teece, 2007), which motivates firms to engage in innovative activities. According to Fagerberg, Mowery and Nelson (2005), these innovative activities are aimed at developing inventions and launching them into the market. For Dosi (1988), the innovation process is cumulative as it depends on the accumulation of technological knowledge (Nelson \& Winter, 2009), but there is a relevant degree of uncertainty. Another important characteristic is that innovation process is contingent on different aspects, such as the industrial sector (Pavitt, 1984) and the national or regional innovation system in which the firm is inserted (Lundvall, 2007; Nelson, 1993). According to Nelson (1993), the national innovation system (composed by a network of institutions such as government, local industry, universities, research institutes) influences the level of innovativeness of the firms and, at the same time, is leveraged by the innovativeness of its institutions.

We argued in the previous section that studies focussing on the effect of innovation on the economic performance of regions and countries are scarcer than those focussing on firm performance. Although this scarcity of studies on this topic is real, several authors have investigated this relationship at the country or regional level. One of the most used measures for regional or national development is the absolute growth of GDP or GDP per capita (Ahlstrom, 2010; Galindo \& Méndez, 2014; Giulioni, 2011; Heidenreich, 2009; Howells, 2005; Kiselitsa, Shilova, \& Liman, 2017). Other authors considered alternative proxies, such as Gini index, which calculates the income distribution of the population (Galindo \& Méndez, 2014), unemployment rate (Moutinho et al., 2015; Smit, 2017), gross value added

\section{Levers of national development}


INMR

18,2

(Moutinho et al., 2015), capital stock, foreign direct investments and human capital (Capello \& Lenzi, 2016).

According to the endogenous growth theory, economy grows according to decisions taken by institutions inside the system (such as the firms in the region evaluated) as well as by technology (Romer, 1994). This theory bases the supposition that innovation introduced by local firms is an essential factor in promoting regional development and economic growth, which was supported by several empirical studies (Ahlstrom, 2010; Kiselitsa et al., 2017). Heidenreich (2009), for instance, concluded in his study that innovation has promoted economic growth in several regions of Europe. Kiselitsa et al. (2017) found similar results in Russia. Paula and Silva (2019) studied the effect of product and process innovations on the economic development of Brazilian states, reporting that process innovation was positively related to economic growth in the medium and long terms. With regard to these findings, Trinh (2017) argued that the set of innovations introduced by firms in a region shifts up the capital accumulation curve in relation to the GDP growth, allowing regions with stronger development of high technological innovation to have a GDP growth higher than that of others with the same level of capital accumulation but with lower innovative rate. This phenomenon occurs because innovation usually generates new businesses, jobs and sources of tax collection (Ahlstrom, 2010). Although innovative firms may drop the less innovative ones from the market (Christensen, 2013), this trade-off should be positive because some of the old incumbents may not fail, but become more innovative and expand instead. This shift may increase the market share as well as the production efficiency and economic growth of a country (Shefer \& Frenkel, 2005). The above-cited arguments support a positive relationship between innovation and regional development.

If a firm's innovativeness is essential for regional and national development, it is necessary to understand how to improve its innovation performance. Patents and R\&D have an intrinsic relationship with innovation and scholars and practitioners recognise this relationship. Global innovation index (GII), one of the most accepted indicators of national innovativeness, is calculated based on several national indicators of innovation inputs and outputs. Patents and other intellectual property rights (IPRs) are variables considered in one of the dimensions of innovation outputs: knowledge and technology outputs (Dutta et al., 2019). $R \& D$ spending is considered in the dimension of innovation inputs called human and capital research (Dutta et al., 2019).

$R \& D$ spending has a direct influence on innovation. Some authors use total R\&D spending or R\&D intensity (i.e. ratio of R\&D spending and total revenues) as a proxy of innovativeness of firms (Lavie \& Rosenkopf, 2006; Stam \& Wennberg, 2009). However, not all R\&D efforts will turn into effective innovation. Some part of the R\&D spending may be wasted in ineffective activities or non-promising technologies. Only a share of the R\&D activities will turn into an innovation. Therefore, it is more appropriate to consider R\&D spending as a proxy of internal innovation efforts. Several authors investigated the influence of R\&D spending on innovation, finding positive results (Belussi, Sammarra, \& Sedita, 2010; Hagedoorn \& Wang, 2012; Zaheer \& Bell, 2005), indicating that the effort to produce internal knowledge is highly related to its effective generation and application.

R\&D investments, besides generating innovation directly, also influence the organisation's capacity to absorb, transform and apply external knowledge through the development of absorptive capacity (Cohen \& Levinthal, 1990). Therefore, from the perspective of a firm, not only internal R\&D improves innovation, but also external knowledge produced by the R\&D of other organisations, such as suppliers, competitors, clients, universities and government (Paula \& Silva, 2017). This complementarity of R\&D from different stakeholders to induce innovation performance at the firm level should also 
be true at the regional and national levels (Risso \& Carrera, 2019; Tirelli \& Spinesi, 2019), as the more innovative organisations from a region are, the more innovative outputs this regional innovation network produces (Rutten \& Boekema, 2007).

As considered by the GII, patents are one of the outputs of the innovation process. Patentbased variables are commonly used as proxies of innovation performance, especially regarding the product innovation. Some examples are number of patents (Hagedoorn \& Wang, 2012; Schilling, 2015; Tortoriello, 2015), number of patent citations (Nieto \& Santamaría, 2007; Soh \& Subramanian, 2014; Yayavaram \& Chen, 2015) and patent's commercial value (Fischer \& Leidinger, 2014). However, patent-based variables are not ideal proxies of innovation (Chambers, 2016) as some firms choose not to patent because of the risk of copying (Hall et al., 2014). In fact, patents are more appropriate for specific sectors, such as the science-based ones (Pavitt, 1984). Also, many patented technologies are not effectively introduced to the market due to lack of commercial potential, underdevelopment of infrastructure to make technology available and strategic decisions made by the patent owner.

Another important discussion when considering the use of patents in empirical studies is that there exist different concepts as to the number of patents to be used. The most observed differentiation is between patent applications and granted patents. Patent applications correspond to a request to register an invention in a patent office, being the result of the first stage of the patenting process (EPO, 2020). Granted patents, in turn, are the ones recognised by the patent office at the end of the patenting process as being a product or a process which provides new solutions, guaranteeing to the applicant firm a temporary right of exclusive commercial exploitation (WIPO, 2020). Granted patents could be considered more appropriate as a proxy of innovation when the firm insists on going to the end of this long process, with high costs along the way, which indicates confidence that this patent is indeed a valuable innovation. However, the time required for a patent to be granted is usually long (in 2013, it was around 11 years in Brazil, between three years in Europe, and 2.4 years in the USA, according to Júnior \& Moreira, 2017). Furthermore, although the applicant cannot guarantee exclusivity for commercial exploitation by law enforcement during the application process, the patent application provides warning to firms that they could be prosecuted if they copy if the patent is granted (OC Patent Lawyer, 2020). Besides, patent applications may indicate more technologically cutting-edge innovation and tend to bring a complete picture of the variety of technological activities of a firm (Belderbos, Faems, Leten, \& Looy, 2010). We could find both types of patents used in empirical studies. For instance, granted patents were used by Hagedoorn and Wang (2012), Liu, Lu, Filatotchev, Buck, and Wright (2010, and Shilling (2015) as a proxy of innovation performance. In turn, patent applications were used as proxy of inventive productivity in the work of Aharonson, Baum, and Plunket (2008), of knowledge generation in the work of Berry (2014) and of innovation performance in the works of Hall and Bagchi-Sen (2007), Nooteboom, Van Haverbeke, Duysters, Gilsing, and Van den Oord (2007) and Tortoriello (2015).

Although patent data are not a good proxy for innovation performance as it is part of the innovation process outcomes and results from inventive efforts using knowledge developed by R\&D activities, internal and external R\&D should influence the patenting process. Several studies supported this positive relationship (DeCarolis \& Deeds, 1999; Funk, 2014; Soh \& Subramanian, 2014). With regard to the relationship between patents and regional or national economic growth and development, empirical studies present divergent results, as stated in the Introduction section. However, this is theoretically reasonable because cumulative patents can be considered a knowledge stock to be used to make new combinations and patents. And although they do not represent the totality of the innovation

\section{Levers of national development}


INMR

18,2

outcomes of a firm or region, they are part of it. Thereby, it is appropriate to study the conjoint relationship between investments in $R \& D$ depending on the different types of institutions, patents and national economic growth and development. Figure 1 shows the proposed theoretical model and the hypotheses representing these relationships as follows:

H1a. The national level of investments in R\&D made by firms positively influences the level of patent applications in a country.

H1b. The national level of investments in $\mathrm{R} \& \mathrm{D}$ made directly by the government positively influences the level of patent applications in a country.

H1c. The national level of investments in R\&D made by private non-profit organisations positively influences the level of patent applications in a country.

H1d. The national level of investments in R\&D made by public and private higher education institutes (including universities) positively influences the level of patent applications in a country.

H2. The national level of investments in R\&D (by firms, higher-education institutions, private non-profit organisations and government) has an indirect influence on the national development mediated by the level of patent applications in the country.

\section{Method}

To test the hypotheses, we collected data on a sample of 35 countries from the statistics database of the Organization for Economic Co-operation and Development (OECD, 2018) in order to conduct a panel regression analysis. This method was chosen as it consists of a longitudinal model, which is more appropriate to find causal relationships. These data covered the years from 1999 to 2013 (a total of 15 periods). The countries were chosen based on the availability of the necessary data to run the model according to the OECD database. A total of 37 countries had data on some of the variables used in the analysis (variables will be described further). Brazil and Lithuania were not included because there was no R\&D spending data available for these countries in the whole period. The 35 countries used to form our sample were Australia, Austria, Belgium, China, Chile, Czech Republic, Denmark, Estonia, Finland, France, Germany, Greece, Hungary, Iceland, Ireland, Italy, Japan, Latvia,

Figure 1.

Theoretical model

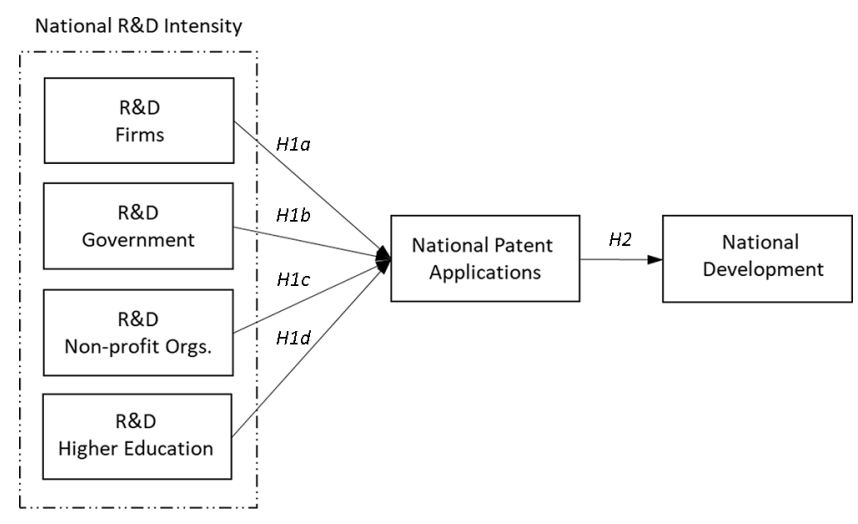


Luxembourg, Mexico, Netherlands, New Zealand, Norway, Poland, Portugal, Russia, Slovakia, Slovenia, Spain, Sweden, South Korea, Switzerland, Turkey, the UK and the USA. Considering the 35 countries and the 15 periods, the total sample comprised 525 cases.

The proposed model runs in two stages. The first stage, which tests $H 1 a, H 1 b, H 1 c$ and $H 1 d$, has patent_population (y) as the dependent variable, corresponding to the average of patent applications in the IP5 offices [1] by residents of the country divided by its population in the considered year. Patent applications were chosen instead of granted patents because the OECD database had only the former variable, which precluded the use of the latter in this study.

The independent variables in this first stage are: i) per cent_R\&D_enterprise, which is the total spending in intramural R\&D by firms in the country divided by the gross domestic product (GDP); ii) per cent_R\&D_government, which is the total spending in R\&D by the government, which consists of direct funding of intramural R\&D activities conducted by extra-budgetary government units and non-profit institutes (NPIs) under governmental control, excluding spending in public higher education institutes and fiscal instruments to stimulate R\&D by firms (OECD, 2015), divided the GDP; iii) per cent_R\&D_higher_education, which is the total spending in R\&D by private and public higher education institutes, as defined by the Frascati Manual (OECD, 2015), divided the GDP; iv) per cent_R\&D_private_non_profit_orgs, which is the total spending in internal R\&D by private non-profit organisations divided the GDP; v) per cent_full_time_researchers, which is the control variable representing the total of full-time researchers divided by the population; vi) population, which is the control variable counting the total population of the country (divided by 1,000); vii) Asia, which is a dummy variable that is 1 (one) if the country is in Asia or 0 (zero) if it is not; viii) Europe, which is a dummy variable that is 1 (one) if the country is in Europe or 0 (zero) if it is not; ix) Oceania, which is a dummy variable that is 1 (one) if the country is in Oceania or 0 (zero) if it is not; $\mathrm{x}$ ) LA, which is a dummy variable that is 1 (one) if the country is in Latin America or 0(zero) if it is not (if all the four dummy variables are 0 , then the country is in North America); and xi) patent_population (year-1), which is the total patents by population in the previous year. The R\&D spending variables were all defined according to the institutional sector (variables $i$ to iv) and to the Frascati Manual (OECD, 2015). Equation (1) represents the first stage:

$$
\begin{aligned}
\text { patent_population }(y)= & \beta a 0+\beta a 1^{*} \% \text { r\&d_enterprise } \\
& +\beta a 2^{*} \% \_r \& d \_g o v e r n m e n t+\beta a 3^{*} \% \_r \& d \_h i g h e r \_e d u c a t i o n \\
& +\beta a 4^{*} \% \_r \& d \_ \text {private_non_profit_orgs } \\
& +\beta a 5^{*} \% \_ \text {full_time_researchers }+\beta a 6^{*} \text { population } \\
& +\beta a 7^{*} A \text { sia }+\beta a 8^{*} \text { Europe }+\beta a 8^{*} \text { Oceania } \\
& +\beta a 9^{*} L A+\beta a 10^{*} \text { patent_population }(y-1)+\varepsilon
\end{aligned}
$$

The second stage, in turn, is intended to verify the influence of patent applications in country performance/development, which was proposed by $H 2$. To achieve this goal, we run three different regressions for each of the following dependent variables:

- GNI_PC (gross national income per capita);

- GDP_PC (gross domestic product per capita); and
Levers of national development 
INMR

18,2

182

- HDI (human development index).

As independent variables, the model presents (iv) patent_regression, which is the result of the calculation of patent_population by using equation (1) in the first stage. This is more appropriate than taking patent_population as the error variance decreases with the former method; (v) per cent_full_time_researchers; (vi) population; (vii) Asia; (viii) Europe; (ix) Oceania; (x) LA; and (xi) dependent variable (year-1), which is the dependent variable in the previous year. Equation (2) represents the second stage:

$$
\begin{aligned}
{\left[G N I \_P C ; G D P \_P C ; H D I\right](y)=} & \beta a 0+\beta a 1^{*} \text { patent_regression } \\
& +\beta a 2^{*} \% \_ \text {full_time_researchers }+\beta a 3^{*} \text { population } \\
& +\beta a 4^{*} A \text { sia }+\beta a 5^{*} \text { Europe }+\beta a 7^{*} \text { Oceania } \\
& +\beta a 8^{*} L A+\beta a 9^{*}\left[G N I \_P C ; G D P \_P C ; H D I\right](y-1) \\
& +\varepsilon
\end{aligned}
$$

We chose robust least-squares to run these panel regressions. This choice was justified because this method is more reliable to check for normality deviations and heteroscedasticity (Moutinho et al., 2015), which were problems in the data. The software EViews was used for robust least squares (RLS) analysis of the 268 cases from all the cases, after the exclusion of those (country/year) with missing data.

\section{Results}

Table 1 shows the average of the variables of the model in the period from 1999 to 2013 (some data are missing for some years and not considered in the average), GII of 2013 (last year of the panel) and 2019 (last GII available). The average for each continent is also shown. One can perceive that North America (represented only by the USA) has most patent applications in the proportion of its population, followed by Asia and Europe. The USA also has more investments in R\&D by firms and private non-profit organisations (followed in both cases by Asia) as well as by the government (followed by Oceania). With regard to higher education institutes (e.g. universities), Oceania and Europe are the leaders. One can also observe that the proportion of full-time researchers in relation to the population is higher in Europe, followed by Asia.

Table 2 shows the Pearson's correlations for the averages of variables and GII of 2013 and 2019. One can see that the 2013 and $2019 \mathrm{GII}$ are strongly correlated, showing that the level of innovativeness in each country has not significantly changed in the last seven years, thus reinforcing the applicability of this analysis today. The results show that GII is highly correlated with the proportion of patents by population as well as with the percentage of R\&D spending by firms and higher education institutes. The correlation is also strong, with the proportion of full-time researchers in the population. These strong correlations were already expected because the GII framework considers the level of innovation inputs (which includes R\&D spending and number of researchers) and outputs (including national patents). A not expected finding was that $R \& D$ investments from the government (excluding public universities) and non-profit organisations is not correlated with GII.

The results found by the RLS analysis supported most of the hypotheses. Table 3 shows the results of the first stage of the model in which hypothesis $\mathrm{Hla}$ (positive effect of firms' internal R\&D spending on patent applications) and $H 1 d$ (positive effect of higher education 


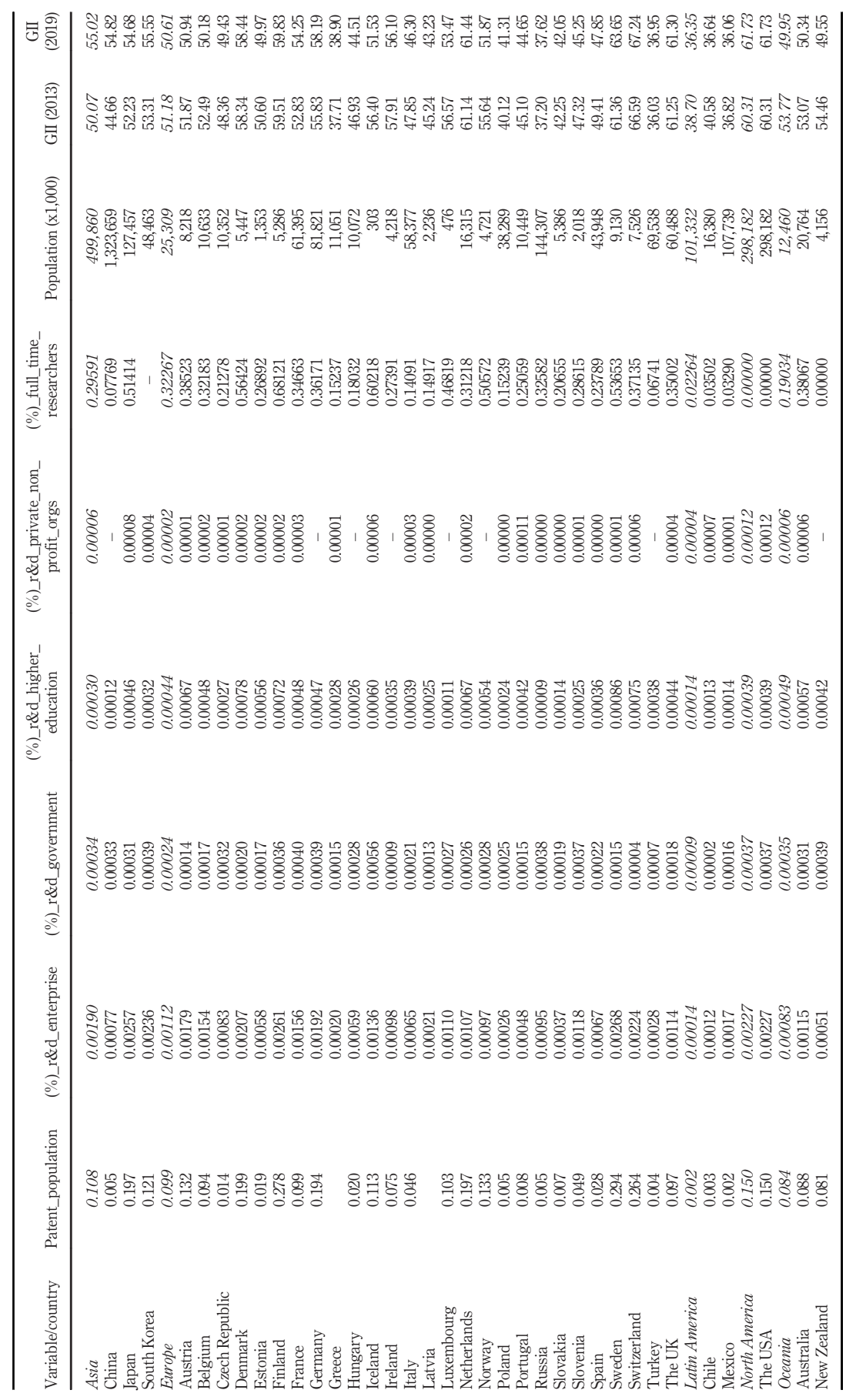

Table 1. Characteristics of the sample (avg. 1999 to 2013, and GII 2013 and 2019) 
INMR
18,2

184

Table 2.

Pearson's correlations

\begin{tabular}{|c|c|c|c|c|c|c|c|c|c|}
\hline & 1 & 2 & 3 & 4 & 5 & 6 & 7 & 8 & 9 \\
\hline 1 - patent_population & 1.000 & $0.877 * *$ & 0.094 & $0.791 * *$ & 0.132 & $0.677 * *$ & -0.179 & $0.823 * *$ & * $0.829 * *$ \\
\hline 2-\%_r\&d_enterprise & & 1.000 & 0.298 & $0.642^{* * *}$ & 0.276 & $0.682 * *$ & -0.022 & $0.722 * *$ & *0.787** \\
\hline 3-\%_r\&d_government & & & 1.000 & -0.019 & 0.111 & 0.264 & 0.176 & 0.177 & 0.189 \\
\hline 4-\%_r\&d_higher_education & & & & 1.000 & 0.133 & $0.633 * *$ & -0.288 & $0.715^{* * *}$ & *0.676** \\
\hline 5-\%_r\&d_private_non_profit_orgs & & & & & 1.000 & -0.048 & $0.444 *$ & $=0.298$ & 0.270 \\
\hline 6-\%_full_time_researchers & & & & & & 1.000 & -0.275 & $0.574 * *$ & $* 0.530 * *$ \\
\hline 7 - population (x1000) & & & & & & & 1.000 & -0.143 & 0.100 \\
\hline 8 - GII(2013) & & & & & & & & 1.000 & $0.945^{* *}$ \\
\hline 9 - GII(2019) & & & & & & & & & 1.000 \\
\hline
\end{tabular}

Notes: $* p<0.05 ; * * p<0.01$

\begin{tabular}{llr}
\hline & Coeff. & S.E. \\
\hline Predictors & & 0.007 \\
$\%$ r\&d_enterprise & $0.027^{* * * *}$ & 0.004 \\
$\%$ r\&d_government & 0.000 & 0.006 \\
\%_r\&d_higher_education & $0.021^{* * * *}$ & 0.004 \\
$\%$ r\&d_private_non_profit_orgs & -0.004 & 0.004 \\
\%_full_time_researchers & $-0.021^{* * * *}$ & 0.021 \\
population & 0.007 & 0.018 \\
Asia & $0.181^{* * * *}$ & 0.006 \\
Europe & $0.022^{* * *}$ & 0.026 \\
Oceania & $0.052^{* * *}$ & 0.020 \\
LA & 0.030 & 0.007 \\
patent_population $(y-1)$ & $0.985^{* * *}$ & \\
Model Fit & & \\
Adj. ${ }^{2}$ & 0.705 & \\
Adj. Rw & 0.997 & \\
Prob (Rn ${ }^{2}$ stat.) & 0.000 &
\end{tabular}

Notes: $* p<0.1 ; * p<0.05 ; * * * p<0.001$

institutes' R\&D spending on patent applications) were supported. This confirms the vocation of firms and universities for basic and applied research (mainly firms), which turns into patented technologies. On the other hand, the effect of R\&D investments from government and private non-profit organisations did not have a positive effect on patent applications, which is reinforced by the rejection of $H 1 b$ and $H 1 c$.

The second step of the analysis supported H2 (see Table 4). The three country development indicators (i.e. GNI per capita, GDP per capita and HDI) were positively influenced by the ratio of patent applications to population. Therefore, the direct influence of patents in a country's development indicates an indirect positive effect of R\&D investments by firms and higher education institutions mediated by patent applications.

\section{Discussion and final remarks}

This article studied the influence of national R\&D spending from different sources in the country development mediated by the level of patent applications. This subject is important 


\begin{tabular}{|c|c|c|c|c|c|c|c|}
\hline \multirow[b]{2}{*}{ Dependent variable } & \multicolumn{2}{|c|}{$G N I \_C$} & \multicolumn{2}{|c|}{$G D P \_p C$} & \multicolumn{2}{|c|}{$H D I$} & 8 \\
\hline & Coeff. & S.E. & Coeff. & S.E. & Coeff. & S.E. & mat \\
\hline \multicolumn{7}{|l|}{ Predictors } & \\
\hline patent_regression & $0.031 * * *$ & 0.009 & $0.021 * * *$ & 0.008 & $0.020 * * *$ & \multirow{8}{*}{$\begin{array}{l}0.007 \\
0.006 \\
0.032 \\
0.018 \\
0.009 \\
0.039 \\
0.016 \\
0.007\end{array}$} & \\
\hline$\%$ _full_time_researchers & $-0.012^{*}$ & 0.007 & $-0.011^{*}$ & 0.006 & $-0.013^{* *}$ & & \\
\hline population & -0.032 & 0.027 & -0.036 & 0.023 & $-0.155^{* * * *}$ & & \\
\hline Asia & $0.086^{* * *}$ & 0.022 & $0.076 * * *$ & 0.019 & $0.107 * * * *$ & & 185 \\
\hline Europe & $0.075 * * *$ & 0.009 & $0.068^{* * *}$ & 0.008 & $0.035 * * *$ & & \\
\hline Oceania & 0.074 & 0.051 & 0.068 & 0.044 & 0.046 & & \\
\hline$L A$ & $0.059 * * *$ & 0.020 & $0.039 * *$ & 0.017 & 0.010 & & \\
\hline [GNI_PC; GDP_PC; HDI] $(y-1)$ & $0.988^{* * * *}$ & 0.008 & $0.994^{* * * *}$ & 0.008 & $0.940^{* * * *}$ & & \\
\hline $\begin{array}{l}\text { Model Fit } \\
\text { Adj. } R^{2}\end{array}$ & 0.837 & & 0.824 & & 0.767 & & Tabl \\
\hline Adj. Rw & 0.996 & & 0.996 & & 0.998 & & Robust least squares \\
\hline Prob (Rn2 stat.) & 0.000 & & 0.000 & & 0.000 & & $\begin{array}{r}\text { (country } \\
\text { development }\end{array}$ \\
\hline \multicolumn{7}{|c|}{ Notes: $* p<0.1 ; * * p<0.05 ; * * * p<0.001$} & variables) \\
\hline
\end{tabular}

as different stakeholders have limited resources and the strategic choice of investing in R\&D represents a deviation from the focus of other areas. R\&D investments can contribute in different ways, besides generating patents. For instance, it can help develop basic science to seek more risky and long-term technologies which may become disruptive innovations. It also can stimulate the development of specialised human resources which can contribute to the national development in the future. However, although recognising that national R\&D investments have other contributions, we investigated only the influence of R\&D in patent applications in the development of a country.

Our findings supported the existence of a positive influence of R\&D investments made by firms and universities (public and private) in the national development and mediated by the total amount of patent applications from a country in the IP5 offices. The same patent mediation was not observed with investments made directly by extra-budgetary government units, controlled NPIs (which do not include public universities and other higher education institutes) and private non-profit organisations.

Patent applications, although not an ideal proxy of innovation, are an indication of the intensity of technological capabilities at the firm and national levels (which is supported by their participation in the GII). Consequently, they tend to have a positive influence on indicators of national development. $\mathrm{R} \& \mathrm{D}$ investments from the other two sources (i.e. government and non-profit organisations) are possibly more effective as inputs for nonpatented innovation, which could mediate their influence on national development. Another interesting finding was that the influence of patent application exists not only when economic measures of national development are used (i.e. GDP and GNI), but also regarding HDI. Unlike GDP and GNI, HDI is a measure of economic and social development based on various indices and is more appropriate for measuring the population's well-being.

These results have relevance to practice. The importance of governmental policies to foster innovation is widely recognised. Our findings are interesting in that national governments can bring inputs to the choice of innovation policies to promote patenting and national development more effectively. Our analyses indicated that fiscal instruments to stimulate R\&D investments by private firms, such as tax deferrals, allowances and credits (OECD, 2003), and investments in applied research conducted by universities might be more effective than directly financing R\&D activities through governmental research institutes or 
INMR

18,2

supporting non-profit organisation for fomenting patent applications. The results showed that R\&D spending by firms and higher education institutes is strongly correlated with patent rate and national development indicators. Although our database did not differentiate public and private universities, the former usually have autonomy to decide where to spend their budget, which does not happen with extra-budgetary government units and NPIs as they are controlled by the government. In this sense, they have many similarities with private universities who are seriously interested in conducting R\&D to develop academic and scientific knowledge through budget management. From our point of view, the fact that a university is private or public does not necessarily change the nature of its activities, meaning that both contribute to national R\&D and innovation as they can be grouped. In such context, government financing of research in public and private universities (in Brazil, for instance, $C A P E S, C N P Q$ and state agencies) also seems to be very important as they invest in $R \& D$, which increases the patent rates. In fact, the government has an essential role as the orchestrator of the national innovation system, especially in emerging economies. Therefore, it is crucial to better direct the scarce resources from the taxpayers to more effective innovation policies in order to foster national development and benefit a maximum number of people.

This study is not without limitations. The first one is that we used patent applications instead of granted patents because information on patents granted by the IP5 offices was not available. However, as explained in the Introduction section, the long time period for granting a patent and the possible use of patents applied but not granted to develop new products, services and processes justify our choice. One more limitation concerns the variable per cent_r\&d_higher_education, which considered public and private investments in higher education institutes together. Separation of both sources of financing would be more appropriate to allow more robust conclusions about the suitability of the government investments to fund $R \& D$ and whether they should be focussed on higher education institutions or not. However, the separation of public and private higher institutions was not possible because the OECD database provides these data together and the conclusions regarding this subject should be considered with care. Another limitation is that the study used only three proxies of national development (i.e. GNI per capita; GDP per capita; HDI), although the literature identified others such as Gini index and unemployment rate, which have different natures. The inclusion of such proxies could have amplified the impact of the variables related to inequality. Another variable that could serve as a dependent variable is GII, which, although it is not a proxy of national development itself, measures the country innovativeness, which influences national development. However, our panel data has patent applications from 1999 to 2013, whereas GII covers the period from 2010 to 2013 only, making its use as a dependent variable impracticable. One more limitation is that not all countries in the sample were considered because of missing data in some years, which made us to disregard the country as a whole. Even with these limitations, this study brought interesting theoretical and practical implications by identifying the importance of investments in R\&D from specific sources at national level. This effectively results in patent applications and has a positive effect on the national development when considering not only economic measures, but also a more complete proxy such as the HDI.

\section{Note}

1. IP5 is a set of the five world's largest intellectual property offices. They are the US Patent and Trademark Office (USPTO), the European Patent Office (EPO), the Japan Patent Office (JPO), the 
Korean Intellectual Property Office (KIPO), and the China National Intellectual Property Administration (CNIPA).

\section{References}

Aharonson, B. S., Baum, J. A., \& Plunket, A. (2008). Inventive and uninventive clusters: The case of Canadian biotechnology. Research Policy, 37(6-7), 1108-1131. doi: https://doi.org/10.1016/j. respol.2008.04.008.

Ahlstrom, D. (2010). Innovation and growth: How business contributes to society. Academy of Management Perspectives, 24(3), 11-24.

Amara, N., Landry, R., \& Traoré, N. (2008). Managing the protection of innovations in knowledgeintensive business services. Research Policy, 37(9), 1530-1547. doi: https://doi.org/10.1016/j. respol.2008.07.001.

(2016). J. Ateljević, \& J. Trivić, (Eds.). cE, Switzerland: Springer. Onomic development and entrepreneurship in transition economies: Issues, obstacles and perspectives.

Belderbos, R., Faems, D., Leten, B., \& Looy, B. V. (2010). Technological activities and their impact on the financial performance of the firm: Exploitation and exploration within and between firms. Journal of Product Innovation Management, 27(6), 869-882. doi: https://doi.org/10.1111/j.15405885.2010.00757.x.

Belussi, F., Sammarra, A., \& Sedita, S. R. (2010). Learning at the boundaries in an "open regional innovation system": A focus on firms' innovation strategies in the Emilia Romagna life science industry. Research Policy, 39(6), 710-721. doi: https://doi.org/10.1016/j.respol.2010.01.014.

Beugelsdijk, S. (2007). Entrepreneurial culture, regional innovativeness and economic growth. Journal of Evolutionary Economics, 17(2), 187-210. doi: https://doi.org/10.1007/s00191-006-0048-y.

Capello, R., \& Lenzi, C. (2016). Innovation modes and entrepreneurial behavioral characteristics in regional growth. Small Business Economics, 47(4), 875-893. doi: https://doi.org/10.1007/s11187016-9741-x.

Chambers, J. (2016). The Obsolescence of Patent Proxies as Country and Firm Innovation Measure. Dissertation, Doctor of Philosophy, Southern New Hampshire University, Manchester, NH.

Christensen, C. M. (2013). The innovator's dilemma: When new technologies cause great firms to fail, Cambridge: Harvard Business Review Press.

Cohen, W. M., \& Levinthal, D. A. (1990). Absorptive capacity: A new perspective on learning and innovation. Administrative Science Quarterly, 35(1), 128-152. doi: https://doi.org/10.2307/ 2393553.

DeCarolis, D. M., \& Deeds, D. L. (1999). The impact of stocks and flows of organizational knowledge on firm performance: An empirical investigation of the biotechnology industry. Strategic Management Journal, 20(10), 953-968. doi: https://doi.org/10.1002/(SICI)1097-0266(199910) 20:10<953::AID-SMJ59>3.0.CO;2-3.

Dosi, G. (1988). The nature of innovation process, in G. Dosi, C. Freeman, R. Nelson, G. Silvergerg, \& L. Soete, (Eds), Technical change and economic theory, pp. 221-238. London: Francis Pinter and New York, NY: Columbia University Press.

Du, J., Leten, B., \& Vanhaverbeke, W. (2014). Managing open innovation projects with science-based and market-based partners. Research Policy, 43(5), 828-840. doi: https://doi.org/10.1016/j. respol.2013.12.008.

Dutta, S., Lanvin, B., \& Wunsch-Vincent, S. (2019). Global innovation index 2019: Creating healthy lives - The future of medical innovation, Ithaca, Fontainebleau, and Geneva: World Intellectual Property Organization (WIPO).

EPO. (2020). How to apply for a European patent. Retrieved from: www.epo.org/applying/basics.html 
INMR 18,2

Fagerberg, J., Mowery, D. C., \& Nelson, R. R. (Eds.) (2005). The Oxford Handbook of Innovation, Oxford university press.

Fischer, T., \& Leidinger, J. (2014). Testing patent value indicators on directly observed patent value An empirical analysis of ocean Tomo patent auctions. Research Policy, 43(3), 519-529. doi: https://doi.org/10.1016/j.respol.2013.07.013.

Funk, R. J. (2014). Making the most of where you are: Geography, networks, and innovation in organisations. Academy of Management Journal, 57(1), 193-222. doi: https://doi.org/10.5465/ amj.2012.0585.

Galindo, M. Á., \& Méndez, M. T. (2014). Entrepreneurship, economic growth, and innovation: Are feedback effects at work? Journal of Business Research, 67(5), 825-829. doi: https://doi.org/ 10.1016/j.jbusres.2013.11.052.

Giulioni, G. (2011). The product innovation process and GDP dynamics. Journal of Evolutionary Economics, 21(4), 595-618. doi: https://doi.org/10.1007/s00191-010-0216-y.

Gupta, S., Malhotra, N. K., Czinkota, M., \& Foroudi, P. (2016). Marketing innovation: A consequence of competitiveness. Journal of Business Research, 69(12), 5671-5681. doi: https://doi.org/10.1016/j. jbusres.2016.02.042.

Hagedoorn, J., \& Wang, N. (2012). Is there complementarity or substitutability between internal and external R\&D strategies? Research Policy, 41(6), 1072-1083. doi: https://doi.org/10.1016/j. respol.2012.02.012.

Hall, L. A., \& Bagchi-Sen, S. (2007). An analysis of firm-level innovation strategies in the US biotechnology industry. Technovation, 27(1-2), 4-14. doi: https://doi.org/10.1016/j. technovation.2006.07.001.

Hall, B. H., \& Sena, V. (2017). Appropriability mechanisms, innovation, and productivity: Evidence from the UK. Economics of Innovation and New Technology, 26(1-2), 42-62. doi: https://doi.org/ 10.1080/10438599.2016.1202513.

Hall, B., Helmers, C., Rogers, M., \& Sena, V. (2014). The choice between formal and informal intellectual property: A review. Journal of Economic Literature, 52(2), 375-423. doi: https://doi.org/10.1257/ jel.52.2.375.

Hamel, G., \& Valikangas, L. (2004). The quest for resilience. Revista Icade. Revista de Las Facultades de Derecho y Ciencias Económicas y Empresariales, (62), 355-358.

Heidenreich, M. (2009). Innovation patterns and location of European low-and medium-technology industries. Research Policy, 38(3), 483-494. doi: https://doi.org/10.1016/j.respol.2008.10.005.

Howells, J. (2005). Innovation and regional economic development: A matter of perspective? Research Policy, 34(8), 1220-1234. doi: https://doi.org/10.1016/j.respol.2005.03.014.

Jemala, M. (2017). New research study on technology patents progress in developing EU countries. International Journal of Agile Systems and Management, 10(2), 116-136. doi: https://oi.org/ 10.1504/IJASM.2017.086153.

Júnior, S. S. G., \& Moreira, J. D. J. S. (2017). O backlog de patentes no brasil: O direito à razoável duração do procedimento administrativo. Revista Direito GV, 13(1), 171-203. doi: https://doi.org/10.1590/ 2317-6172201708.

Kiselitsa, E., Shilova, N. N., \& Liman, I. (2017). Regional features of the innovative activity formation as a determining factor in the development of the Russian economy. Academy of Strategic Management Journal, 16, 96.

Lavie, D., \& Rosenkopf, L. (2006). Balancing exploration and exploitation in alliance formation. Academy of Management Journal, 49(4), 797-818. doi: https://doi.org/10.5465/ amj.2006.22083085.

Lee, Y., John, C. S., Fong, E. A., \& Bao, Y. (2018). Flexible new product development processes and appropriability: Intellectual property and first-mover. International Journal of Innovation Management, 22(1), 1850002 doi: https://doi.org/10.1142/S1363919618500020. 
Liu, X., Lu, J., Filatotchev, I., Buck, T., \& Wright, M. (2010). Returnee entrepreneurs, knowledge spillovers and innovation in high-tech firms in emerging economies. Journal of International Business Studies, 41(7), 1183-1197. doi: https://doi.org/10.1057/ jibs.2009.50.

Lundvall, B. A. (2007). National innovation systems - Analytical concept and development tool. Industry \& Innovation, 14(1), 95-119. doi: https://doi.org/10.1080/13662710601130863.

Merges, R. P. (1988). Commercial success and patent standards: Economic perspectives on innovation. California Law Review, 76(4), 803-876. doi: https://doi.org/10.2307/3480538.

Moutinho, R., Au-Yong-Oliveira, M., Coelho, A., \& Pires Manso, J. (2015). The role of regional innovation systems (RIS) in translating R\&D investments into economic and employment growth. Journal of Technology Management \& Innovation, 10(2), 9-23. doi: https://doi.org/ 10.4067/S0718-27242015000200002.

Nelson, R. (1993). National innovation systems: A comparative analysis, Cambridge, MA: Oxford University Press.

Nelson, R., \& Winter, S. (2009). An evolutionary theory of economic change, Cambridge, MA: Harvard University Press.

Nieto, M. J., \& Santamaría, L. (2007). The importance of diverse collaborative networks for the novelty of product innovation. Technovation, 27(6-7), 367-377. doi: https://doi.org/10.1016/j. technovation.2006.10.001.

Nooteboom, B., Van Haverbeke, W., Duysters, G., Gilsing, V., \& Van den Oord, A. (2007). Optimal cognitive distance and absorptive capacity. Research Policy, 36(7), 1016-1034. doi: https://doi. org/10.1016/j.respol.2007.04.003.

OC Patent Lawyer. (2020). Patent pending: Definition, benefits and warning. Retrieved from: https:// ocpatentlawyer.com/patent-pending-definition-benefits-warning/

OECD. (2003). Tax incentives for research and development: Trends and issues. Retrieved from: www. oecd.org/sti/inno/2498389.pdf

OECD. (2005). Oslo Manual-Guidelines for collecting and interpreting innovation data, Paris: OECD Publishing.

OECD. (2015). Frascati manual 2015: Guidelines for collecting and reporting data on research and experimental development, Paris: OECD Publishing.

OECD. (2018). OECD.Stat. Retrieved from: https://stats.oecd.org/

Orihata, M. (2001). National economic maturity and product innovation: The case of Japan. International Journal of Entrepreneurship and Innovation Management, 1(1), 111-124. doi: https://doi.org/10.1504/IJEIM.2001.000448.

Paula, F. O., \& Silva, J. F. (2017). Innovation performance of Italian manufacturing firms: The effect of internal and external knowledge sources. European Journal of Innovation Management, 20(3), 428-445. doi: https://doi.org/10.1108/EJIM-12-2016-0119.

Paula, F. O., \& Silva, J. F. (2018). The impact of alliances and internal R\&D on the firm's innovation and financial performance. Brazilian Business Review, 15(6), 533-550. doi: https://doi.org/10.15728/ bbr.2018.15.6.2.

Paula, F. O., \& Silva, J. F. (2019). The role of innovation for leveraging regional development. Revista Pretexto, 20(1), 72-83. doi: https://doi.org/10.21714/pretexto.v20i1.6016.

Pavitt, K. (1984). Sectoral patterns of technical change: Towards a taxonomy and a theory. Research Policy, 13(6), 343-373. doi: https://doi.org/10.1016/0048-7333(84)90018-0.

Risso, W. A., \& Carrera, E. J. S. (2019). On the impact of innovation and inequality in economic growth. Economics of Innovation and New Technology, 28(1), 64-81.

Romer, P. M. (1994). The origins of endogenous growth. Journal of Economic Perspectives, 8(1), 3-22. doi: https://doi.org/10.1257/jep.8.1.3. 
INMR 18,2

Rutten, R., \& Boekema, F. (2007). Regional social capital: Embeddedness, innovation networks and regional economic development. Technological Forecasting and Social Change, 74(9), 1834-1846. doi: https://doi.org/10.1016/j.techfore.2007.05.012.

Ryu, H. S., \& Lee, J. N. (2018). Understanding the role of technology in service innovation: Comparison of three theoretical perspectives. Information \& Management, 55(3), 294-307. doi: https://doi. org/10.1016/j.im.2017.08.003.

Schilling, M. A. (2015). Technology shocks, technological collaboration, and innovation outcomes. Organization Science, 26(3), 668-686. doi: https://doi.org/10.1287/orsc.2015.0970.

Schumpeter, J. A. (1934). The theory of economic development - An inquiry into profits. Capital, credit, interest and the business cycle, Cambridge, MA: Harvard University Press.

Shearmur, R., \& Bonnet, N. (2011). Does local technological innovation lead to local development? A policy perspective. Regional Science Policy \& Practice, 3(3), 249-270. doi: https://doi.org/10.1111/ j.1757-7802.2011.01040.x.

Shefer, D., \& Frenkel, A. (2005). R\&D, firm size and innovation: An empirical analysis. Technovation, 25(1), 25-32. doi: https://doi.org/10.1016/S0166-4972(03)00152-4.

Smit, A. (2017). Does the lack of innovation impact the competitiveness of businesses and poverty levels of African countries? International Journal of Economic Research, 14(12), 275-285.

Soh, P. H., \& Subramanian, A. M. (2014). When do firms benefit from university-industry R\&D collaborations? The implications of firm R\&D focus on scientific research and technological recombination. Journal of Business Venturing, 29(6), 807-821. doi: https://doi.org/10.1016/j. jbusvent.2013.11.001.

Stam, E., \& Wennberg, K. (2009). The roles of R\&D in new firm growth. Small Business Economics, 33(1), 77-89. doi: https://doi.org/10.1007/s11187-009-9183-9.

Statistics Times (2019). List of countries by projected GDP per capita. Retrieved from: http:// statisticstimes.com/economy/countries-by-projected-gdp-capita.php

Su, H. N., \& Lin, Y. S. (2018). How do patent-based measures inform product commercialization? - The case of the United States pharmaceutical industry. Journal of Engineering and Technology Management, 50,24-38. doi: https://doi.org/10.1016/j.jengtecman.2018.08.002.

Teece, D. J. (2007). Explicating dynamic capabilities: The nature and microfoundations of (sustainable) enterprise performance. Strategic Management Journal, 28(13), 1319-1350. doi: https://doi.org/ 10.1002/smj.640.

Terjesen, S., \& Patel, P. C. (2017). In search of process innovations: The role of search depth, search breadth, and the industry environment. Journal of Management, 43(5), 1421-1446. doi: https:// doi.org/10.1177/0149206315575710.

Tirelli, M., \& Spinesi, L. (2019). R\&D financing and growth. Economics of Innovation and New Technology, 1-24.

Tortoriello, M. (2015). The social underpinnings of absorptive capacity: The moderating effects of structural holes on innovation generation based on external knowledge. Strategic Management Journal, 36(4), 586-597. doi: https://doi.org/10.1002/smj.2228.

Trinh, T. (2017). A primer on GDP and economic growth. International Journal of Economic Research, 14(5), 13-24.

Wang, M. Y., Lo, H. C., \& Liao, Y. Y. (2015). Knowledge flow determinants of patent value: Evidence from Taiwan and South Korea biotechnology patents. International Journal of Innovation and Technology Management, 12(03) doi: https://doi.org/10.1142/S0219877015400040.

WIPO. (2020). Patents: What is a patent. Retrieved from: www.wipo.int/patents/en/

Yamakawa, Y., Yang, H., \& Lin, Z. J. (2011). Exploration versus exploitation in alliance portfolio: Performance implications of organizational, strategic, and environmental fit. Research Policy, 40(2), 287-296. doi: https://doi.org/10.1016/j.respol.2010.10.006. 
Yayavaram, S., \& Chen, W. R. (2015). Changes in firm knowledge couplings and firm innovation performance: The moderating role of technological complexity. Strategic Management Journal, 36(3), 377-396. doi: https://doi.org/10.1002/smj.2218.

Zaheer, A., \& Bell, G. G. (2005). Benefiting from network position: Firm capabilities, structural holes, and performance. Strategic Management Journal, 26(9), 809-825. doi: https://doi.org/10.1002/ smj.482.

\section{About the authors}

Fábio de Oliveira Paula (ORCID is an Assistant Professor of Strategy at the Pontifical Catholic University of Rio de Janeiro (PUC-Rio). The author has a PhD in Business Administration at PUC-Rio, in the research field of Strategy (2017). The author has a FAPERJ Doctorate-Sandwich scholarship from September 2016 to August 2017, having conducted academic research at Aalto University School of Business (Helsinki, Finland). The author has a MSc degree in Business Administration at PUC-Rio (2006). Graduated in Computer Engineering at the same university (2001). The author conducts research and has articles published in international academic journals of high impact and presented at international conferences in the fields of Innovation Management, Strategy and Alliance Networks. The author is a Project Manager with PMP certification, worked in firms of several industries, such as retail, foreign trade, marketing, education, information technology and oil and gas, for 13 years. Fábio de Oliveira Paula is the corresponding author and can be contacted at: fabioop@ iag.puc-rio.br

Jorge Ferreira da Silva (ORCID: is a Professor of Strategy and International Business at the Pontifical Catholic University of Rio de Janeiro (PUC-Rio) and one of the top researchers in the area of Business Administration in the ranking of the National Council for Scientific and Technological Research (CNPq). Dr Da Silva has published in national and international journals, such as the Journal of Business Research, European Journal of Innovation Management, Journal of International Entrepreneurship, Latin American Business Review and Brazilian Administration Review. Dr Da Silva was Vice-Dean of Graduate Programs at IAG Business School during 15 years and President of ANPAD, the Brazilian Academy of Management, from 2010 to 2015. Prior to his academic career, Dr Da Silva was a Vice-President of leading Brazilian firms in the Information Technology area. He is an electronic engineer and has a $\mathrm{PhD}$ in Industrial Engineering from PUC-Rio.

\section{Levers of national development}

For instructions on how to order reprints of this article, please visit our website:

www.emeraldgrouppublishing.com/licensing/reprints.htm

Or contact us for further details: permissions@emeraldinsight.com 